\title{
Monitoring protocols for biological weapons
}

The reality of biological weapons was underscored by the recent Las Vegas anthrax scare and the latest Iraqi bioweapons inspection showdown. Given this reality, we support the position taken by the British government (as discussed in the commentary by John Walker and Tony Phillips, p. 310) that a meaningful biological weapons convention must acknowledge the need for monitoring, not only suspected terror states, but also the rest of the world. Although there aren't any official bioweapons programs in industrialized nations, any defensive program against naturally or unnaturally occurring pathogens can be "weaponized." Such a recognition brings with it a long list of thorny technical, legal, and other problems that directly affect the biotechnology and related industries, and in whose solutions we must become directly involved.

A biological weapons convention banning the development and use of bioweapons was agreed to in 1972 and signed by 158 countries (although not subsequently ratified by all). This agreement, while a good moral beginning, contains no protocols for monitoring and verifying compliance with the convention on the part of all the signatories. But global morality is not what it purported to be in 1972, and a 21 st century weapons convention clearly must have such protocols.

The most difficult problems associated with universal monitoring come from the dual use potential of much biotechnology equipment and processes. The same fermenters that make hepatitis vaccine antigens can produce neurotoxins or botulins. It is not possible to confirm by visual inspection that only beneficial products are being made, which makes some sort of sample analysis necessary. How does one protect the rights of companies and academic institutions in the signing countries from the inadvertent disclosure of their trade secretsthe bugs or vectors at the heart of new and valuable pathogen-fighting drugs or pesticides-if not from outright espionage, on the part of inspectors enforcing the terms of the convention?

As the piece by Walker and Philips makes clear, we need to both devise protocols that solve the problems referred to above, and find precise answers to such questions as: What research and what facilities need to be monitored? How often do sites need to be visited? Who does the monitoring? What steps are to be taken if the development of weapons is suspected?

It is essential that the biotechnology and pharmaceutical communities become visibly and actively involved in these formulations. Without such involvement, the drafting, let alone the ratification, of any effective bioweapons convention will remain a noble but Sisyphean exercise. We have both pragmatic reasons and moral obligations to participate.

\section{A shot in the arm for DNA vaccines}

In biotechnology, one can never quite tell where the next commercial opportunity is going to come from, as the story of the Oxford-based drug delivery company, PowderJect Pharmaceuticals, illustrates.

PowderJect is a small company that has leveraged itself into a strong intellectual property position. In March, GlaxoWellcome signed a deal potentially worth $\$ 300$ million for the development of PowderJect's hepatitis B and other DNA vaccines. Data from animal studies indicate that its DNA vaccine formulations reduce the amount of DNA needed for the vaccine 2000-fold-clearly a technical and clinical advantage. But it is the origins of PowderJect's technology that are possibly the most interesting aspects of the company. They are in plant biotechnology.

In the mid-1980s, plant genetic engineering had a problem: The major grain crops-maize, wheat, and rice-didn't want to be engineered. When protoplasts of these dicotyledenous plants were transformed with foreign DNA, the protoplasts would not regenerate. Cursedly, these same crops were also refractive to transformation with the vector based on the Ti plasmid of Agrobacterium tumefaciens, the vector that had been successfully used for engineering tobacco, soy, and numerous other monocotyledenous species.

The solution, it turned out, was biolistics. John Sanford at Cornell University demonstrated that it was possible to transform plant cells using an explosive charge to propel microscopic tungsten particles coated with DNA directly into plant cells and nuclei. Others quickly took up the mantle. Researchers at Agracetus, for instance, developed an alternative method of propelling DNA into plant cells based on accelerating gold particles through an electric field. Within a few years, biolistics had created transgenic varieties of rice, maize, and wheat.
But who owned the intellectual property? Sanford licensed his fundamental patent on biolistics to DuPont, retaining only rights to the use of the technique in ornamental plants. DuPont and Agracetus then, in effect, cross-licensed their two approaches. Agracetus applied the technology to plants (the rights to which were acquired by Monsanto in mid-1996), and DuPont and the W.R. Grace subsidiary, Auragen, developed a gold particle-based method for gene delivery into mammalian cells.

In parallel with these advances, researchers at the University of Oxford were developing another method for blasting particles into cells-compressed helium. Their primary aim was to deliver drug formulations through the skin, the gums, or other routes. That technology, and its attendant rights to therapeutic uses of biolistics, was subsequently licensed to PowderJect.

The three methods of particle acceleration came together in December 1996, when PowderJect and Auragen established Geniva, a $50 / 50$ joint venture in the development of genetic vaccines. Subsequently, as Grace divested non-core businesses, PowderJect bought Grace out of Geniva using money raised in a public flotation.

The parable of PowderJect tells us three things about building a potentially substantial business as a startup company. First, you have to be lucky; it is doubtful, for example, whether Novartis-a company with strong interests in both agriculture and gene therapy-would have relinquished any rights to biolistics as readily as Grace and DuPont did. Second, you then have to persist in a directed commercial and technical strategy. And finally, only by developing effective technology and by ensuring that others cannot block your route to market can you guarantee a payback for your efforts. 